\title{
Effect of Post-Heat-Treatment on Various Characteristics of Commercial Pitch-Based Carbon Fibers
}

\author{
Sung Bong Yoon ${ }^{1}$, Chae Wook Cho ${ }^{1}$, Donghwan Cho ${ }^{1, \uparrow}$, Jong Kyoo Park ${ }^{2}$ and Jae Yeol Lee \\ ${ }^{1}$ Department of Polymer Science and Engineering, Kumoh National Institute of Technology, Gumi, Gyungbuk 730-701, Korea \\ ${ }^{2}$ Polymer Composite Lab, Agency for Defense Development, Yuseong 35-4, Daejeon, Korea \\ "e-mail:dcho@kumoh.ac.kr \\ (Received March 9, 2007; Accepted June 7, 2007)
}

\begin{abstract}
In this study, commercially available pitch-based carbon fibers of general grade were post-heat-treated using a boxtype high temperature furnace at $1800^{\circ} \mathrm{C}, 2000^{\circ} \mathrm{C}, 2200^{\circ} \mathrm{C}$, and $2400^{\circ} \mathrm{C}$, respectively. The fundamental characteristics of each heat-treated carbon fibers were investigated in terms of chemical composition, morphology, thermal stability, $\mathrm{X}$-ray diffraction, single filament tensile test, and electrical resistivity. The result showed that the fiber properties were significantly influenced by the post-heat-treatment, indicating the greater effect with increasing treatment temperature. The carbon contents, thermal stability, and tensile properties of the carbon fibers used here were further increased by the post-heat-treatment, whereas the $d$-spacing between graphene layers and the electrical resistivity were reduced with increasing post-heat-treatment temperature.
\end{abstract}

Keywords : Pitch-based carbon fiber, Post-heat-treatment, Characteristics

\section{1. 서 론}

탄소섬유(carbon fiber)는 일반 유기섬유와 달리 매우 독특 한 구조적, 열적, 기계적 특성뿐만 아니라 열전도성과 전기전 도성을 지니고 있기 때문에, 지난 수 십여 년 동안 학문과 산 업적 측면뿐만 아니라 스포츠/레저 및 자동차/항공우주 부품 소재 등 여러 분야에 다양하게 사용되어 왔으며, 현재에도 새 로운 응용 분야의 개발을 위해 널리 연구되고 있는 첨단소재 이다 $[1,2]$. 탄소섬유는 지금까지 알려진 소재 중에서 가장 높 은 비(specific)기계적 물성을 지니므로 고분자는 물론 금속 및 세라믹 소재의 보강재로 널리 사용되어 왔다. 아울러 탄소섬 유는 제조 시 사용한 전구체(precursor) 섬유 종류 및 열처리 공정 조건에 따라 다른 물성을 나타내므로 물성 등급에 따라 여러 분야에서 다양하게 응용될 수 있다.

일반적으로 탄소섬유의 제조는 산업 현장에서 불활성 조건 하에 약 $1400^{\circ} \mathrm{C}$ 이상의 고온에서 탄화 또는 선택적으로 흑연 화 공정를 행한다[3]. 프리커서 섬유를 안정화공정을 거쳐 탄 화시킬 경우 섬유에 가해지는 여러 공정조건에 따라 얻어지는 최종 섬유의 물성은 크게 달라질 수 있으며, 그 중에서도 최 종 열처리온도가 가장 중요한 역할을 하는 것으로 알려져 있 다. 예를 들면, 탄소섬유의 화학적, 물리적 특성과 미세구조는 물론 열적, 기계적, 전기적 특성 등은 탄소섬유 제조 시 사용 된 최종 열처리온도에 크게 좌우된다. 그리고 열처리온도 수 준에 따라 탄소섬유의 물성은 물론 장비비용과 공정비용에도 크게 영향을 미치므로 사용 목적에 맞는 최종 열처리온도의
선정이 반드시 필요하다.

핏치계(Pitch-based) 탄소섬유는 coal-tar 또는 petroleum 핏 치를 사용하여 용융방사, 안정화, 탄화, 흑연화, 표면처리 및 사이징처리 같은 일련의 공정을 거쳐 제조된다[4-7]. 일반적으 로 등방성(isotropic) 핏치로부터 범용 핏치계 탄소섬유가 얻어 지고, 주로 이방성(anisotropic 또는 mesophase) 핏치로부터 보 다 우수한 핏치계 탄소섬유가 얻어질 수 있다. 또한, 불활성 분위기에서 약 $1200^{\circ} \mathrm{C}-1600^{\circ} \mathrm{C}$ 사이의 열처리온도에 따라 다 른 등급의 범용 핏치계 탄소섬유가 제조되며, 물론 $3000^{\circ} \mathrm{C}$ 이 전에 사용된 최고 열처리온도 수준이 높을수록 최적의 조건하 에서 여러 등급의 고성능 핏치계 탄소섬유가 제조될 수 있다. 핏치계 탄소섬유는 PAN계(polyacrylonitrile-based) 탄소섬유에 비해 독특한 특성을 지니고 있다 $[8,9]$. 최적화된 흑연화 공정 조건에서 제조된 핏치계 탄소섬유는 흑연의 이론적 인장탄성 률(약 $1000 \mathrm{GPa})$ 에 접근할 수 있으며, 일반적으로 고강도 PAN 계 탄소섬유보다 강도는 낮으나 탄성률은 더 높다. 또한 핏치 계 탄소섬유는 PAN계 탄소섬유보다 더 우수한 열전도도와 전 기전도도 특성을 지니고 있다.

따라서, 본 연구의 목적은 최종열처리온도가 약 $1800^{\circ} \mathrm{C}$ 이 하에서 제조된 기존의 상업용 핏치계 탄소섬유에 대하여 약 $1800^{\circ} \mathrm{C}-2400^{\circ} \mathrm{C}$ 사이의 고온에서 추가적으로 열처리공정을 행 하여 얻은 탄소섬유에 대하여 화학조성, 열안정성, 미세구조, 인장특성 및 전기특성을 조사하는 것이다. 이는 연속식으로 제 조된 탄소섬유에 대하여 뱃치(batch)식 후속 고온열처리 공정 을 통하여 기존의 상업용 핏치계 탄소섬유의 기본 특성을 이 
해하며 탄소함량과 결정구조의 향상을 꾀하는 동시에 기계적 특성과 전기전도성을 증가시키어 향후 탄소섬유의 응용 가능 성을 더욱 증대시키기 위함이다. 또한, 본 연구는 저온영역에 서 탄화된 상대적으로 저가의 핏치계 탄소섬유를 고온영역에 서 추가로 열처리하여 고가의 탄소섬유의 특성을 지닌 소재로 전환시키기 위함이다.

\section{2. 실 험}

\section{1. 재료}

본 연구에서는 상업용으로 제조된 coal-tar 핏치계(Mesophase, Dialead K63712, 12 K, Mitshubishi Rayon Co.) 탄소섬 유가 사용되었다. 탄소섬유는 공급받은 상태 그대로 즉 상업 적으로 사이징(sizing) 처리가 되어 있는 상태 그대로 고온열 처리 공정에 사용되었다. 각 고온열처리 공정 후 얻어진 탄소 섬유는 그대로 특성 분석에 사용하였다.

\section{2. 탄소섬유의 열처리공정}

상업적 목적에 따라 $1800^{\circ} \mathrm{C}$ 이하의 탄화조건 하에서 제조 된 탄소섬유에 대하여 추가적으로 행한 후속 열처리공정이 탄 소섬유의 화학적, 열적, 기계적 특성, 미세구조 및 전기비저항 에 미치는 영향을 조사하였다. 후속 열처리공정은 박스형 고 온열처리로(High Temperature Treatment Furnace: Ace 진공사) 를 이용하여 수행하였다. 여러 다발의 핏치계 탄소섬유 토우 (tow)를 약 $3 \mathrm{~m}$ 정도의 길이로 자른 후, $150 \mathrm{~mm}$ 길이의 흑연 봉(graphite rod)에 토우를 균일하게 감아 열처리공정을 위한 섬유 소재를 준비하였다. 후속 열처리공정은 뱃치식으로 수행 하였다. Fig. 1은 본 실험에 사용된 고온열처리로의 개략도를 보여준다.

고온열처리로 $(600 \mathrm{~mm} \times 600 \mathrm{~mm} \times 600 \mathrm{~mm})$ 내부의 중앙 위치에 흑연봉에 감겨져 있는 탄소섬유를 가지런하게 놓은 후

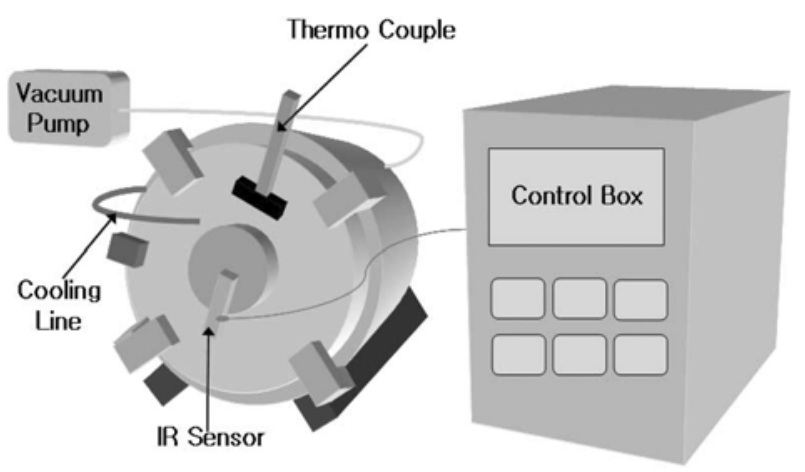

Fig. 1. Schematic illustration of a box-type heat-treatment furnace. The internal working dimensions are approximately 600 $\mathrm{mm} \times 600 \mathrm{~mm} \times 600 \mathrm{~mm}$ with the cubic shape.
챔버뚜껑을 완전히 닫은 상태에서 진공펌프를 이용하여 열처 리로 내부가 완전히 진공상태가 되도록 하였다. 진공이 유지 된 상태에서 초기에는 고순도질소( $99.999 \%)$ 를 충분하게 주입 시킨 후 서서히 질소량을 조절해 가면서 압력게이지가 약간의 양압에 걸리도록 하였다. 열처리공정 중에 장력은 가하지 않 았다. 최종 열처리온도는 $1800^{\circ} \mathrm{C}, 2000^{\circ} \mathrm{C}, 2200^{\circ} \mathrm{C}$ 그리고 $2400^{\circ} \mathrm{C}$ 가 사용되었다. 공정온도 변화는 상온부터 $1200^{\circ} \mathrm{C}$ 까지 R-type 열전쌍을 사용하여 측정하였으며, $1200^{\circ} \mathrm{C}$ 이후에는 적 외선(IR) 온도센서를 이용하여 측정하였다. 실험 전에 미리 수 행한 예비실험을 통하여 열처리온도는 설정온도와 실제온도의 오차가 $\pm 5^{\circ} \mathrm{C}$ 이내가 되도록 보정되었다. 승온속도는 $500^{\circ} \mathrm{C} / \mathrm{h}$ 이었으며, 공정 시 단계적 온도 상승은 적용하지 않았다. 최종 열처리온도에서 30 분 동안 등온 상태를 유지시킨 후 열처리로 는 자연냉각되었다.

\section{3. 화학조성 분석}

고온열처리로부터 얻어진 각각의 탄소섬유에 대한 화학조성 을 조사하기 위하여 원소분석기(Elemental Analyzer, Elementar Vario EL, Elementar Analysensystem)를 사용하였다. 측정 과 정에서 각 탄소섬유 시료는 약 $1150^{\circ} \mathrm{C}$ 에서 분해, 연소되었으 며, 이때 섬유로부터 발생되는 가스로부터 탄소섬유에 포함된 $\mathrm{C}, \mathrm{H}, \mathrm{N}$, 및 $\mathrm{S}$ 화학조성을 분석하였다. 산소 $(\mathrm{O})$ 함량은 전체 $100 \%$ 에서 C, H, N 및 S 함량을 모두 더한 값을 뺀 값으로부 터 계산되었다. 이들 성분 이외의 극소량의 기타 성분은 무시 하였다.

\section{4. 열안정성 조사}

여러 고온열처리 공정을 거친 각각 탄소섬유의 열안정성을 조사하기 위하여 열중량분석기(Thermogravimetric Analyzer, TGA, LABSIS TM, Setaram)를 사용하였다. 알곤가스가 유입 되는 불활성분위기에서 측정하였다. 모든 $\mathrm{TGA}$ 실험은 상온부 터 $1000^{\circ} \mathrm{C}$ 까지 $20^{\circ} \mathrm{C} / \mathrm{min}$ 의 승온속도 조건에서 수행하였다.

\section{5. 미세구조 관찰}

각 고온열처리 조건에서 얻어진 탄소섬유 필라멘트의 섬유 직경과 모폴로지를 관찰하기 위하여 주사전자현미경(Scanning electron microscope, SEM, Hitachi, S-570)을 사용하였다. 각 단섬유에 대하여 단면(cross-sectional 또는 transverse) 방향에 서 관찰하였다. 측정에 사용한 모든 시편은 현미경 관찰 시 시 편표면에 전하가 쌓이는 현상을 막고 이미지가 잘 얻어질 수 있도록 백금(pt)으로 코팅하였다.

\section{6. $X$-선 회절 분석}

각 탄소섬유에 대하여 행한 후속 열처리공정의 조건에 따른 


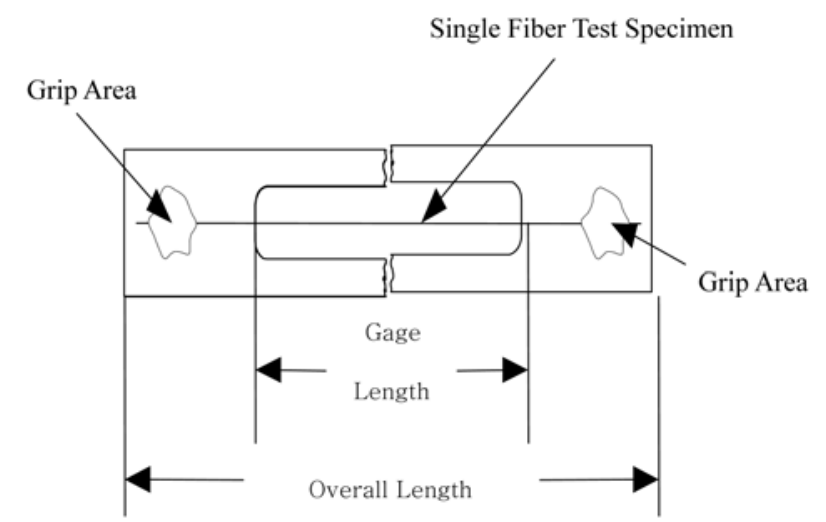

Fig. 2. A lay-out of the specimen for single fiber filament tensile test.

$\mathrm{X}$-선 회절 패턴의 변화를 조사하기 위하여 고분해능 $\mathrm{X}$-선 회 절분석기(High resolution X-Ray Diffractometer, XRD, X'Pert PRO-MNR, Philips)를 사용하였다. 주사(scanning) 범위는 $2 \theta$ $=5^{\circ} \sim 50^{\circ}$ 이었으며, $2 \theta^{\text {는 }} 0.04^{\circ}$ 간격마다 측정되었다. 측정간격 당 소요시간은 1 초였다. 연속형 주사 방법이 적용되었으며, 사 용된 방사광은 $\mathrm{K}_{\alpha}$ 이며, 방사 대상 소재는 $\mathrm{Cu}$ 이었다.

\section{7. 섬유 필라멘트 인장특성 분석}

각 고온열처리 조건에서 얻어진 탄소섬유 필라멘트의 인장 특성의 측정은 ASTM D3379-75에 규정된 단섬유 인장강도 시험(single filament tensile test) 방법에 따라 Instron사의 만 능시험기(UTM-4467)를 사용하여 수행하였다. Fig. 2는 단섬 유 인장강도 시험시편의 형상을 보여주는 그림이다. 사용된 하 중셀(load cell)은 $2.5 \mathrm{~N}$, crosshead 속도는 $1 \mathrm{~mm} / \mathrm{min}$ 그리고 게이지길이(gauge length)는 $25 \mathrm{~mm}$ 이었다. 인장강도는 각 열 처리공정 별로 얻어진 섬유필라멘트마다 10 개 이상의 시편에 대한 평균한 값으로부터 구하였다. 인장특성 계산에 필요한 섬 유필라멘트의 직경은 주사전자현미경(SEM)으로 관찰한 약 20 개의 데이터로부터 얻어진 평균값을 사용하였다.

\section{8. 전기비저항 측정}

각 고온열처리 조건에서 얻어진 탄소섬유 필라멘트의 전기 비저항(electrical resistivity)에 미치는 공정인자의 영향을 조사 하기 위하여 탄소섬유 토우로부터 여러 개의 단섬유 필라멘트 를 발췌하였다. 유리판 위에 단섬유를 놓은 다음 양끝에 은페 이스트(silver paste)를 한 방울 떨어뜨려 고정시킨 다음 측정 에 사용하였다. 전기비저항 측정은 ASL 800 MEGOHMETER (USA)를 사용하여 ASTM B193-87에 의거한 2점탐침법(2point probe method)에 따라 측정하였다. 비저항 계산에 필요 한 섬유필라멘트의 직경은 주사전자현미경으로 관찰한 20 개 데이터로부터 얻어진 평균값을 사용하였다.

\section{3. 결과 및 고찰}

Table 1은 본 연구에서 추가 고온열처리공정으로부터 얻은 핏치계 탄소섬유에 대하여 조사된 화학조성 결과를 보여준다. 여기서 'untreated' 공급받은 상태인 표면처리 및 사이징처리 를 거친 상업용 핏치계 탄소섬유를 의미한다. 그러므로 각 조 건에서 열처리후 섬유표면에 존재하는 유기 사이징 층은 완전 히 제거되었다. Table 1에 보여주는 결과는 'untreated' 섬유를 주어진 네 온도 조건 $\left(1800^{\circ} \mathrm{C}, 2000^{\circ} \mathrm{C}, 2200^{\circ} \mathrm{C}, 2400^{\circ} \mathrm{C}\right)$ 에서 추가로 열처리공정을 행하였을 때 탄소함량은 열처리 전 약 $97 \%$ 에서 $2400^{\circ} \mathrm{C}$ 에서 열처리 후 약 $99 \%$ 까지 약 $2 \%$ 정도 증 가하였다. 반면 질소함량과 수소함량은 큰 변화를 보이지 않 았다. 이 결과는 본 실험에 사용한 핏치계 탄소섬유의 탄소함 량은 $2400^{\circ} \mathrm{C}$ 에서 후속 열처리에 의해 약 $99 \%$ 까지 탄소성분 을 증가시킬 수 있다는 것을 보여준다. 열처리를 하지 않은 경 우 핏치계 탄소섬유에 존재하는 수소와 질소 함량이 상대적으 로 낮은 것으로 보아 방향족 구조에서 수소나 질소에 의한 불 균질성(heterogeneity)이 작음을 예상할 수 있다[10]. 그리고 $1800^{\circ} \mathrm{C}-2200^{\circ} \mathrm{C}$ 사이의 영역에서 보여주는 탄소함량은 전형적 인 메조페이스 핏치의 탄소조성 값에 해당한다.

Fig. 3의 상단에 보여주는 주사전자현미경 관찰 결과는 전 형적인 메조페이스 핏치계 탄소섬유의 단면을 보여준다. 미세 결정구조는 섬유직경에 방사(radial) 방향으로 형성되어 있음 을 확인할 수 있다. Table 2에 표기된 섬유직경은 약 9-10 $\mu \mathrm{m}$ 로 후속 열처리온도 변화에 따라 큰 차이를 보여주지 않았다. 이는 핏치계 탄소섬유에서 저탄성률(LM) 등급부터 고탄성률 $(\mathrm{HM})$ 등급 사이에 섬유직경의 차이가 거의 없다는 사실[9]과 유사한 결과이다.

Fig. 4는 메조페이스 핏치계 탄소섬유의 XRD 패턴 변화에 미치는 열처리공정의 유.무와 후속 열처리온도의 영향을 보여 준다. 그림에서 $2 \theta$ 는 흑연구조의 graphene 면 간의 평균거리 즉 $d$-spacing에 대한 정보를 제공하여 준다. 일반적으로 핏치 계 탄소섬유는 $3000^{\circ} \mathrm{C}$ 전후에서 고온열처리 공정에 의해 흑 연화가 가능한 흑연화성 탄소(graphitizable carbon)으로 이루 어져 있다[4]. 따라서 PAN계 탄소섬유보다 작은 $d$-spacing 값 을 나타낸다. 열처리온도가 증가함에 따라 XRD 피크세기는 상대적으로 낮아지나 피크의 폭은 점점 좁아지는 것으로 보아

Table 1. Chemical compositions of pitch-based carbon fibers untreated and post-heat-treated at different temperatures

\begin{tabular}{cccccc}
\hline HTT $\left({ }^{\circ} \mathrm{C}\right)$ & $\mathrm{C}$ & $\mathrm{H}$ & $\mathrm{N}$ & $\mathrm{S}$ & $\mathrm{O}$ \\
\hline Untreated & 97.23 & 1.19 & 0.39 & 0.30 & 0.89 \\
1800 & 97.26 & 1.56 & 0.42 & 0.53 & 0.23 \\
2000 & 97.39 & 1.26 & 0.39 & 0.36 & 0.60 \\
2200 & 97.87 & 1.48 & 0.31 & 0.40 & 0.04 \\
2400 & 98.97 & 1.16 & 0.40 & 0.36 & 0.00 \\
\hline
\end{tabular}



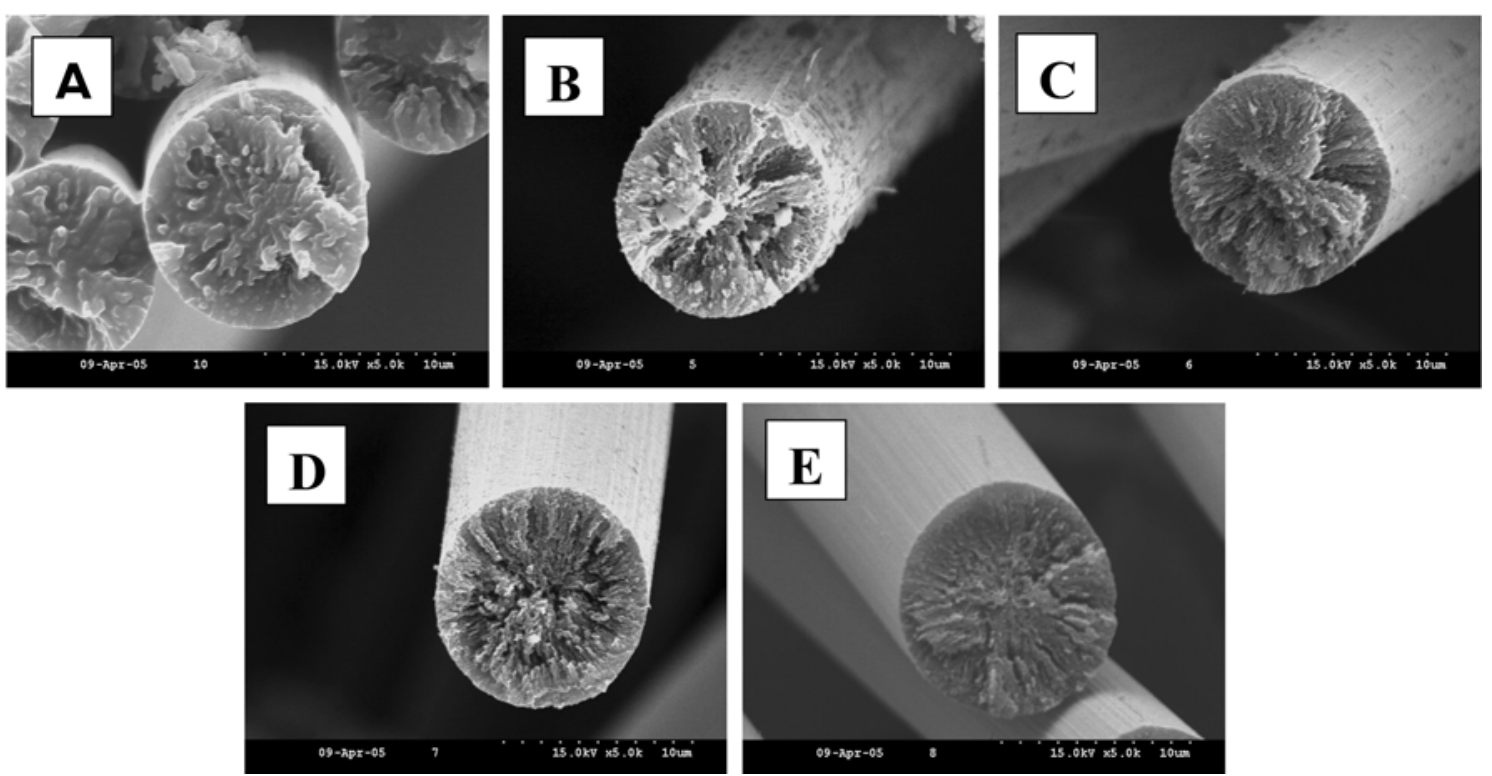

Fig. 3. SEM micrographs showing the pitch-based carbon fiber surfaces untreated (A) and post-heat-treated at $1800^{\circ} \mathrm{C}(\mathrm{B}), 2000^{\circ} \mathrm{C}$ (C), $2200^{\circ} \mathrm{C}(\mathrm{D})$, and $2400^{\circ} \mathrm{C}(\mathrm{E}) .(\times 5000)$

Table 2. A summary of the average fiber diameter of pitchbased carbon fibers untreated and post-heat-treated at different temperatures

\begin{tabular}{cc}
\hline HTT $\left({ }^{\circ} \mathrm{C}\right)$ & Average Fiber Diameter $(\mu \mathrm{m})$ \\
\hline Untreated & 10.07 \\
1800 & 9.68 \\
2000 & 9.94 \\
2200 & 8.96 \\
2400 & 10.01 \\
\hline
\end{tabular}

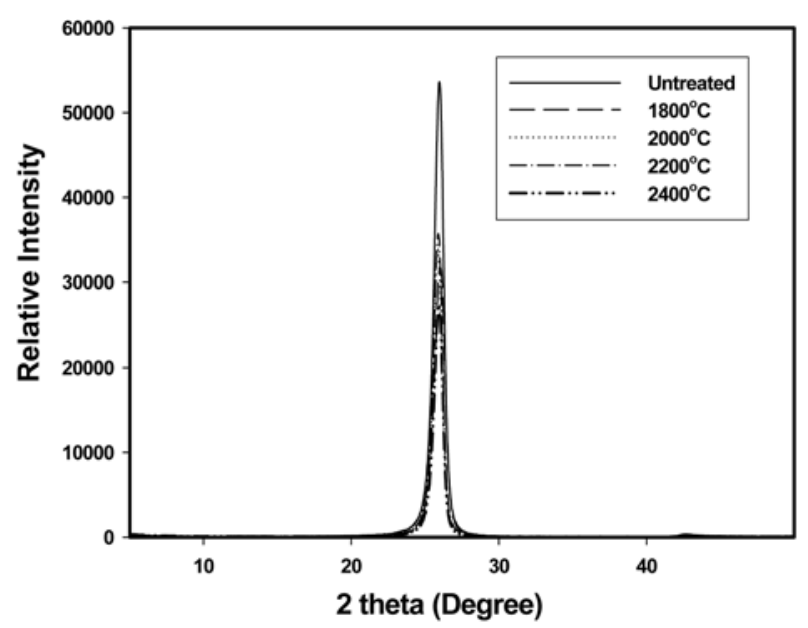

Fig. 4. XRD diffractograms of pitch-based carbon fibers untreated and post-heat-treated at different temperatures.

후속 열처리가 결정구조의 발달에 기여한 것으로 사료된다.

Fig. 5는 핏치계 탄소섬유에 대한 $d$-spacing과 $2 \theta$ 값의 변화

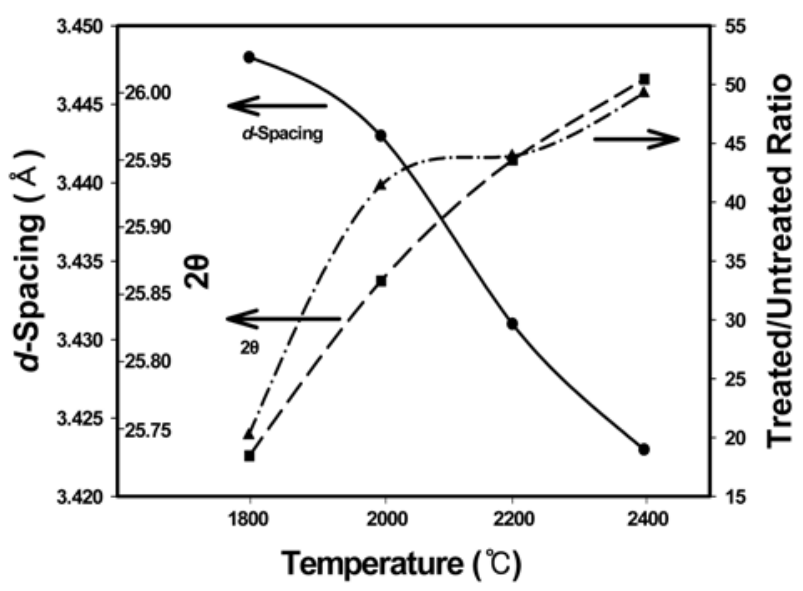

Fig. 5. Variation of the XRD characteristics observed for pitchbased carbon fibers untreated and post-heat-treated at different temperatures.

를 보여준다. 열처리온도가 상승함에 따라 $d$-spacing은 점차적 으로 감소하고, 흑연결정 구조에 점차 접근한다. 그러나 $2400^{\circ} \mathrm{C}$ 에서 후속 열처리공정 후에도 핏치계 탄소는 완전한 흑 연구조에 이르지는 못하고 난층구조(turbostratic structure)를 유지하고 있는 것으로 판단된다. 흑연화도(degree of graphitization)가 낮은 탄소섬유에서 XRD 회절곡선의 폭은 상대적으 로 넓지만 열처리온도가 상승하면서 흑연화가 진행됨에 따라 $2 \theta$ 값은 $26^{\circ}$ 에 가까워지며 $2 \theta$ 피크는 점점 뾰족하게 변화된다. $2 \theta=26^{\circ}$ 는 (002) 회절을 나타내며 이는 흑연(화) 재료에서 전 형적으로 관찰되는 피크이다.

또한, Fig. 5로부터 $2 \theta$ 값은 전형적인 흑연의 (002) 회절을 나타내는 $26^{\circ}$ 에 점차 근접하고 있음을 알 수 있다. 이는 메조 


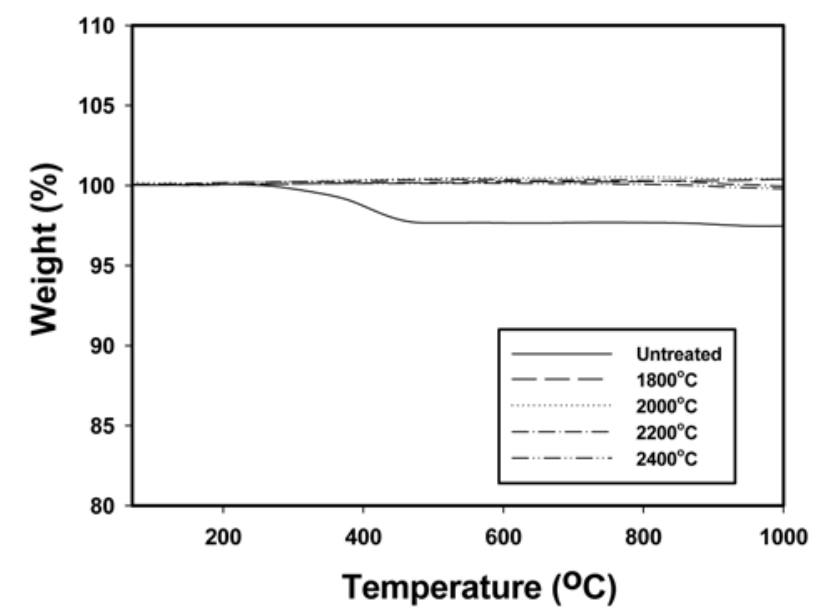

Fig. 6. TGA result obtained for pitch-based carbon fibers untreated and post-heat-treated at different temperatures.

페이스 핏치계 탄소섬유에서 규칙성을 갖고 있는 graphene 층 의 형성이 높은 열처리온도에서 더욱 발달되어 있음을 의미한 다. XRD 회절 곡선에서 'untreated' 시편 대비 'treated' 시편 의 피크높이 비를 나타내는 Treated/Untreated Ratio 값이 열처 리온도가 상승함에 다라 점점 증가하는 경향을 나타내었다. 이 는 XRD 피크는 열처리온도가 증가할수록 더욱 뾰족해졌음을 의미한다. 이상에서 언급한 $\mathrm{XRD}$ 분석 결과로부터 $2400^{\circ} \mathrm{C}$ 에 서 열처리된 탄소섬유는 아직 난층구조를 유지하고 있으며, 기 존의 상업용 핏치계 탄소섬유의 결정성을 더욱 향상시키기 위 해서는 훨씬 높은 열처리온도에서의 후속 공정이 필요할 것으 로 판단된다.

Fig. 6은 'untreated' 및 후속 열처리공정을 거친 네 종류의 핏치계 탄소섬유에 대하여 열중량분석기를 이용하여 불활성분 위기 하에서 측정한 결과이다. 열처리를 하지 않은 것을 제외 한 다른 시편은 측정온도 $1000^{\circ} \mathrm{C}$ 까지 매우 우수한 열안정성 을 보여주었다. 열처리를 하지 않은 경우 약 $400^{\circ} \mathrm{C}$ 이전부터 발생되는 중량감소 등 상대적으로 낮은 열안정성은 상업용 탄 소섬유의 표면에 처리된 사이징제의 분해에 의한 것으로 판단 된다[11]. 열처리 후에는 $1000{ }^{\circ} \mathrm{C}$ 까지 중량감소가 전혀 발생하 지 않는 매우 뛰어난 열안정성을 보여주었다. 본 열안정성 결 과는 사용된 $\mathrm{TGA}$ 기기에서 측정이 가능한 최대온도까지 분 석한 결과이지만 실제로는 그 이상의 온도에서도 열적으로 안 정할 것을 예측된다.

Fig. 7은 후속 열처리를 하지 않은 것과 열처리를 한 네 종 류의 핏치계 탄소섬유에 대한 단섬유 필라멘트 인장특성 분석 결과를 보여준다. 측정 중 섬유필라멘트의 미끄러짐 현상이 없 이 필라멘트 고정이 잘 된 상태에서 실험이 수행되었다. 후속 열처리온도가 증가함에 따라 인장특성이 증가하는 경향을 보 여주었다. 이는 핏치계 탄소섬유가 후속 열처리공정에서 높은 온도에 노출될 때 탄소섬유에 존재하는 미세결함이 결정구조 의 발달과 함께 감소되었기 때문인 것으로 사료된다. 메조페 이스 핏치는 규칙적인 방향족 탄화수소 층을 가지고 있으며,
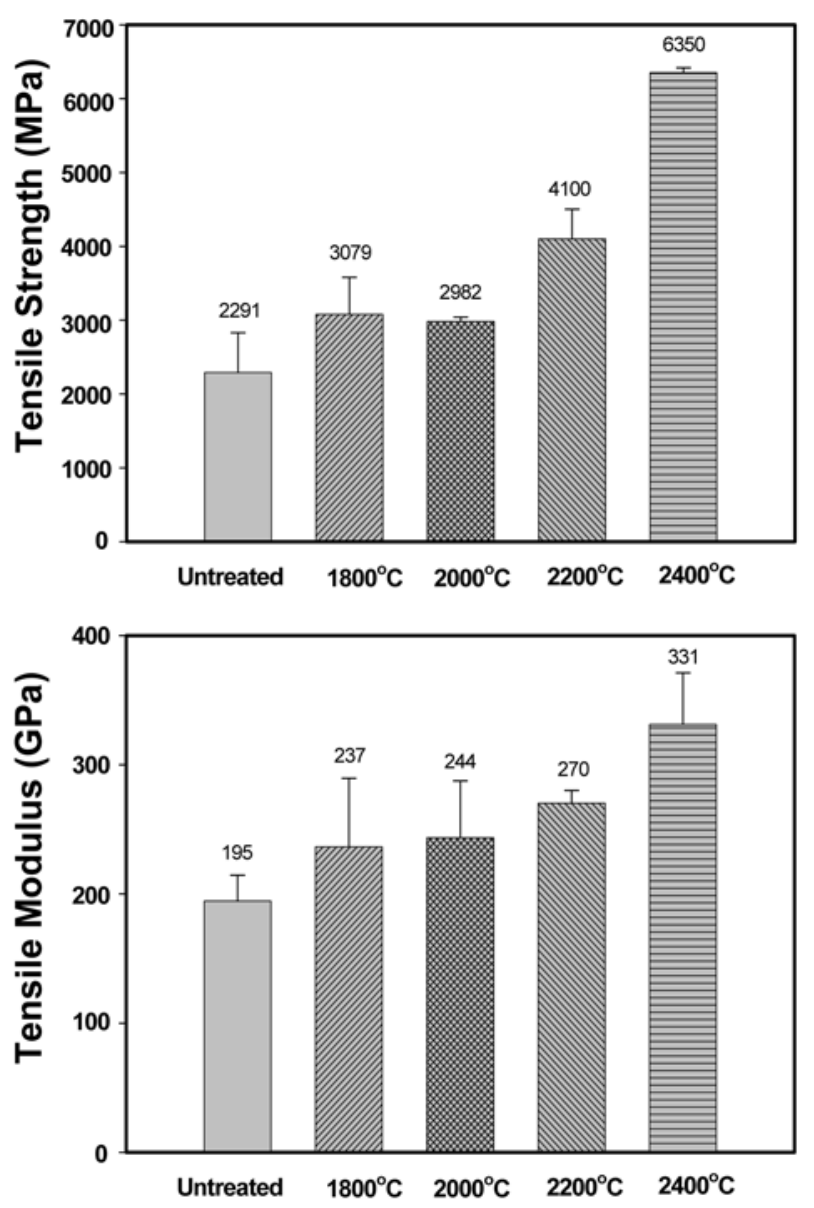

Fig. 7. The tensile strength and modulus measured for pitchbased carbon fibers untreated and post-heat-treated at different temperatures.

헤테로원자의 함량이 낮으며 불순물 함유량 이 매우 낮은 것 도 인장특성 변화에 기여하였을 것으로 판단된다. 인장탄성률 또한 열처리온도가 증가함에 따라 점차적으로 증가하였다. 이 러한 결과는 핏치계 탄소섬유에서 전형적으로 관찰되는 현상 이다[4]. 특히 열처리온도 $2000^{\circ} \mathrm{C}$ 이상에서 크게 증가된 인장 탄성률을 보여준다. 이는 섬유 내부의 결정구조 층의 밀도가 커져 방향족 구조의 배향성이 섬유길이 방향으로 증가하며 질 서도도 더 높아졌기 때문이다.

핏치계 탄소섬유의 특성은 근본적으로 열처리온도 $2000^{\circ} \mathrm{C}-$ $3000^{\circ} \mathrm{C}$ 사이에서 중요하게 변하며 높은 온도에서 그 영향은 더욱 크다. 메조페이스 핏치는 더 크고 보다 규칙적인 방향족 탄화수소 층을 가지고 있으며, $1800^{\circ} \mathrm{C}$ 이상에 노출될 때 방향 족 면(plane)이 쌓여진 층의 형성은 PAN계 탄소섬유나 등방성 핏치계 탄소섬유의 경우보다 더 잘 이루어진다[8]. 섬유배향성 도 더 높아지므로 미세결정 조직의 배향성이 더 빠르게 증가 한다. 미세결정 구조가 성장하는 과정에서 결정층 구조의 이 방성 팽창은 강한 내부 응력을 초래하므로 구조적 결함은 사 라지고 미세 결정층이 재배향하게 된다. 그러므로 메조페이스 


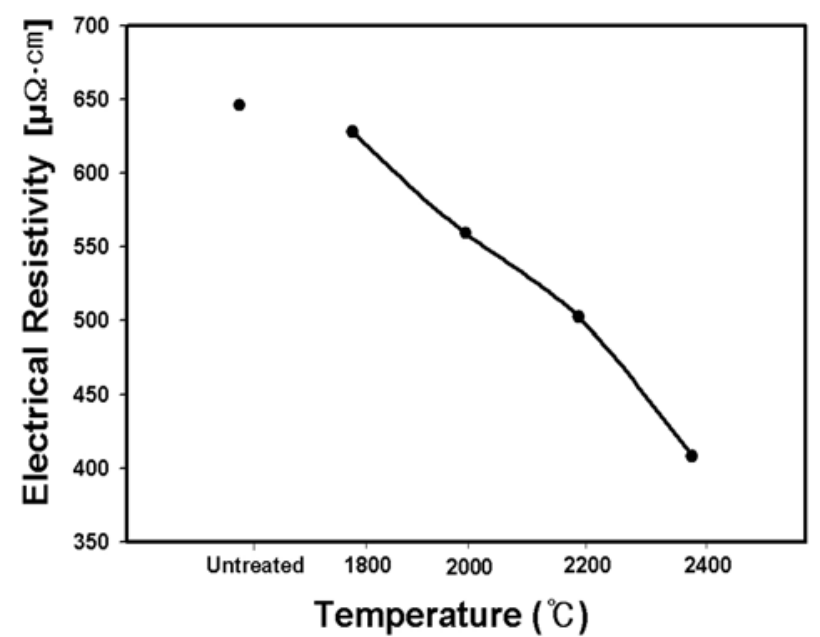

Fig. 8. Variation of the electrical resistivity of pitch-based carbon fibers untreated and post-heat-treated at different temperatures.

핏치는 3 차원적으로 배향된 흑연과 같은(graphite-like) 구조 를 더 쉽게 형성한다. 그러므로 후속 열처리온도가 증가함에 따라 인장강도와 탄성률은 증가하였다고 해석할 수 있다.

Fig. 8은 상업용 핏치계 탄소섬유의 전기비저항에 미치는 후 속 열처리온도의 영향을 보여주는 결과이다. 추가 열처리공정 을 행하지 않은 탄소섬유의 비저항값 $646 \mu \Omega \cdot \mathrm{cm}$ 는 $2400^{\circ} \mathrm{C}$ 에 서 열처리한 후 $408 \mu \Omega \cdot \mathrm{cm}$ 로 약 $37 \%$ 감소되었다. 이러한 결 과는 앞의 탄소함량, $\mathrm{X}$-선 회절분석 및 인장탄성률 결과에서 보여준 경향과도 잘 일치한다. 본 연구에서 얻은 비저항 값은 이와 유사한 열처리조건에서 제조된 핏치계 탄소섬유의 비저 항 값과 거의 비슷하였으며 [9], 열처리온도가 증가함에 따라 비저항 값은 점점 감소하였다. 이는 본 연구에 사용된 상업용 핏치계 탄소섬유가 구조적으로 불완전한 흑연 구조를 갖고 있 지만, 후속 열처리공정에 의해 섬유의 결정구조가 무질서 (disorder) 상태에서 비교적 질서(order)가 있는 상태로 변화되 었음을 의미하는 것이다. 일반적으로 탄소재료에서 전기비저 항은 구조의 질서도가 증가함에 따라, 즉 흑연구조에 가까워 짐에 따라 감소하는 경향을 보인다.

핏치계뿐만 아니라 PAN계 탄소섬유에서 비저항 특성은 섬 유의 미세구조와 결정배향성에 크게 의존한다. 이들 특성들은 앞에서 언급한 탄소섬유의 인장탄성률의 변화와도 매우 밀접 한 관계가 있다[12]. 일반적으로, 탄소섬유의 비저항은 섬유가 경험한 최종 열처리온도에 크게 영향을 받는다. 열처리온도에 따라 섬유의 내부 및 외부 구조가 변화되기 때문이다. 열처리 온도가 증가함에 따라 비저항은 감소하며, 이것은 전하 이동 밀도가 온도 증가에 따라 증가되기 때문이다. 일정온도에서 탄 소섬유의 비저항은 인장탄성률이 증가할수록 감소된다. 그 이 유는 인장탄성률의 증가는 탄소섬유의 결정구조와 질서도를 향상시키는 우선배향성(preferred orientation)을 증가시키며, 이 는 곧 방향족 graphene 층 간격을 좁아지게 하여 전하의 이동
밀도와 운동성을 증가시키는 결과를 초래하기 때문이다.

\section{4. 결론 및 맺음말}

기존의 상업용 메조페이스 핏치계 탄소섬유를 1800,2000 , 2200 및 $2400^{\circ} \mathrm{C}$ 에서 추가적으로 열처리한 후 얻어진 탄소섬 유의 화학조성, 미세구조, X-선 회절, 열안정성, 인장특성 및 전기비저항을 조사하여 열처리 전의 특성과 비교 분석한 결과, 다음과 같은 결론을 얻을 수 있었다.

1. 기존의 핏치계 탄소섬유의 탄소함량은 $2400^{\circ} \mathrm{C}$ 에서 후속 열처리공정에 의해서 약 $99 \%$ 까지 도달하였다. 후속 열처리 전과 비교할 때 탄소함량이 약 $2 \%$ 정도의 증가하였다.

2. 기존의 상업용 핏치계 탄소섬유의 모폴로지는 후속 열처 리에 의해 결정배향성이 향상된 양상을 보여주었으며, 열안정 성도 증가하였으나, 얻어진 탄소섬유의 직경은 크게 영향을 받 지 않았다.

3. 후속 열처리온도가 높아짐에 따라 탄소섬유의 graphene 층 사이의 $d$-spacing이 감소하였으며, (002)회절 특성 피크인 $2 \theta=26^{\circ}$ 에 가까이 근접하였다. 후속 열처리공정에 의해 기존의 핏치계 탄소섬유의 결정구조는 더욱 발달하는 것으로 확인되 었다.

4. 상업용 핏치계 탄소섬유의 인장강도와 탄성률 모두 후속 열처리온도가 높아짐에 따라 증가하는 경향을 나타내었다.

5. 후속 열처리온도가 증가함에 따라 탄소섬유의 전기비저 항은 두드러지게 감소하였다. 또한, $1800^{\circ} \mathrm{C}$ 이상에서의 후속 열처리공정 전에 이미 낮은 비저항 값을 나타내는 것으로 보 아, 섬유축 방향으로 미세구조적으로 어느 정도의 배향이 형 성되었을 것으로 판단되었다.

이상의 결과를 종합하면, 본 연구에 사용된 상업용 핏치계 탄소섬유는 최종 열처리온도가 $1800^{\circ} \mathrm{C}$ 이하에서 탄화되었을 것으로 예측된다. 따라서, 본 연구는 탄화 또는 열처리에 대한 정보가 알려지지 않은 핏치계 탄소섬유에 대한 후속 고온열처 리에 따른 기본 특성 및 최종 탄화온도를 예측할 수 있는 분 석 정보를 제공하여 준다. 또한, 저온탄화 조건에서 연속공정 으로 제조된 핏치계 탄소섬유의 특성을 고온열처리 조건에서 추가로 행하는 뱃치공정에 의해서 기계적 특성과 전기전도성 등이 우수한 탄소섬유로 전환시킬 수 있다는 것을 본 연구결 과로부터 확인하였다. 아울러 본 연구의 결과는 현재 국내에 서 생산되지 않는 탄소섬유를 사용함에 있어, 상대적으로 가 격이 저렴한 등급의 탄소섬유로부터 가격과 물성이 더 뛰어난 탄소섬유로 변화가 가능하다는 것을 함축하고 있다.

\section{References}

[1] Donnet, J.-B.; Wang, T. K.; Peng, J. C. M. P; Rebouillat, S. "Carbon Fibers", $3^{\text {rd }}$ Ed., Marcel Dekker, New York, 
1998, Chapter 7.

[2] Savage, G. "Carbon-Carbon Composites", Chapman \& Hall, London, 1993, Chapter 2.

[3] Peebles, L. H. "Carbon Fibers: Formation, Structure, and Properties", CRC Press, 1995, Chapters 3 and 4.

[4] Edie, D. D. Carbon 1998, 36, 345.

[5] Mochida, I.; Yoon, S.-H.; Takano, N.; Fortin, F.; Kora, Y.; Yokogawa, K. Carbon 1996, 34, 941.

[6] Lafdi, K.; Bonnamy, S.; Oberlin, A. Carbon 1993, 31, 29.

[7] Kim, C.; Lee, S.-H.; Kim, Y.-M.; Yang, K.-S. Carbon Sci- ence 2001, 2, 170.

[8] Huang, Y.; Young, R. J. Carbon 1995, 33, 97.

[9] Lavin, J. G.; Boyington, D. R.; Lahijani, J.; Nystem, B.; Issi, J. P. Carbon 1993, 31, 1001.

[10] Marsh, H; Heintz, E. A.; Rodriquez-Reinoso, F. "Introduction to Carbon Technologies", University of Alicante, Spain, 1997, Chapter 8.

[11] Cho, D. Carbon 1996, 34, 1151.

[12] Cho, D.; Choi, Y.; Park, J. K.; Lee, J. Y. Polym. Sci. Tech. 2000, 11(6), 717. 